Article

\title{
Four New Genes of Cyanobacterium Synechococcus elongatus PCC 7942 Are Responsible for Sensitivity to 2-Nonanone
}

\author{
Olga A. Koksharova ${ }^{1,2, *} \mathbb{C}$, Alexandra A. Popova ${ }^{2,3}$, Vladimir A. Plyuta ${ }^{2} \mathbb{D}$ and \\ Inessa A. Khmel ${ }^{2}$ (D) \\ 1 Belozersky Institute of Physico-Chemical Biology, Lomonosov Moscow State University, Leninskie Gory, \\ 1-40, 119992 Moscow, Russia \\ 2 Institute of Molecular Genetics of National Research Center "Kurchatov Institute", Kurchatov Square, 2, \\ 123182 Moscow, Russia; alexandra.a.popova@gmail.com (A.A.P.); plyutaba@gmail.com (V.A.P.); \\ khmel@img.ras.ru (I.A.K.) \\ 3 Winogradsky Institute of Microbiology, The Federal Research Centre "Fundamentals of Biotechnology" \\ of the Russian Academy of Sciences, Prospekt 60 let Oktyabrya, 7/2, 117312 Moscow, Russia \\ * Correspondence: koksharova@genebee.msu.ru; Tel.: +7-917-534-7543
}

Received: 1 July 2020; Accepted: 11 August 2020; Published: 13 August 2020

\begin{abstract}
Microbial volatile organic compounds (VOCs) are cell metabolites that affect many physiological functions of prokaryotic and eukaryotic organisms. Earlier we have demonstrated the inhibitory effects of soil bacteria volatiles, including ketones, on cyanobacteria. Cyanobacteria are very sensitive to ketone action. To investigate the possible molecular mechanisms of the ketone 2-nonanone influence on cyanobacterium Synechococcus elongatus PCC 7942, we applied a genetic approach. After Tn5-692 transposon mutagenesis, several 2-nonanone resistant mutants have been selected. Four different mutant strains were used for identification of the impaired genes (Synpcc7942_1362, Synpcc7942_0351, Synpcc7942_0732, Synpcc7942_0726) that encode correspondingly: (1) a murein-peptide ligase Mpl that is involved in the biogenesis of cyanobacteria cell wall; (2) a putative $A B C$ transport system substrate-binding proteins MlaD, which participates in $A B C$ transport system that maintains lipid asymmetry in the gram-negative outer membrane by aberrantly localized phospholipids transport from outer to inner membranes of bacterial cells; (3) a conserved hypothetical protein that is encoding by gene belonging to phage gene cluster in Synechococcus elongatus PCC 7942 genome; (4) a protein containing the VRR-NUC (virus-type replication-repair nuclease) domain present in restriction-modification enzymes involved in replication and DNA repair. The obtained results demonstrated that 2-nonanone may have different targets in Synechococcus elongatus PCC 7942 cells. Among them are proteins involved in the biogenesis and functioning of the cyanobacteria cell wall (Synpcc7942_1362, Synpcc7942_0351, Synpcc7942_0732) and protein participating in stress response at DNA restriction-modification level (Synpcc7942_0726). This paper is the first report about the genes that encode protein products, which can be affected by 2-nonanone.
\end{abstract}

Keywords: microorganisms; genetic control; 2-nonanone; VOCs; ABC-transporter; cell membranes; resistant mutants; transposon mutagenesis; DNA restriction-modification; ketone toxicity

\section{Introduction}

Volatile organic compounds (VOCs) are diverse organic molecules (alcohols, ketones, aldehydes, acids, terpenoids, sulfur-containing compounds, etc.) that are producing by bacteria, fungi, plants, and animals. VOCs play an important role in communication between organisms in natural communities and are considering as "infochemicals" in ecological microbiology by 
now [1-9]. The microbial volatile database "mVOC" is available [2]. The volatiles have a wide range of effects: antimicrobial action, stimulation or suppression of plant growth, animal (nematode and insects) attraction or deterrence [4-7]. VOCs may participate in the regulation of bacteria cellular processes, in the communication of bacteria and their interaction with higher organisms $[3,4,6,8]$. Rhizosphere bacteria of Pseudomonas and Serratia genera are known to produce volatiles providing antagonistic activity of these strains against a number of prokaryotic (heterotrophic bacteria, cyanobacteria) and eukaryotic organisms (fungi, nematodes, Drosophila) [5-7]. In our previous study, it was found that the ketones 2-nonanone $(14.4 \pm 5.0 \%)$ and 2-undecanone $(12.0 \pm 3.6 \%)$ were in bacterial VOCs mixture [7]. Microbial volatiles ketones demonstrate different types of biological activity [3]. The detailed molecular mechanisms of the effects of ketones on bacteria, fungi, algae, and plants are not known. Due to their high lipophilicity, ketones can easily penetrate membranes of bacteria cells and these organic molecules may modify the membrane chemical structure through nucleophilic addition between carbonyl groups and acetyl amine groups [9]. The permeability for lipophilic molecules like ketones depends on their acyl chain length. So, the biological effects of ketones may depend on the ketone molecule size. Ketones can form Schiff bases with protein amino groups and therefore lead to disruption of normal protein activity [10,11]. It was demonstrated that ketones bind with protein (bovine serum albumin) [12]. Moreover, 2-nonanone and 2-undecanone demonstrated an inhibitory action on protein refolding in bacteria [13], which can suppress the expression of genes involved in Quorum Sensing regulation in bacterial cells [14] and negatively affected biofilm formation by Agrobacterium tumefaciens [15].

Strong inhibitory effect of 2-nonanone, 2-heptanone, and 2-undecanone was shown in different taxonomic groups of organisms, including cyanobacteria (Synechococcus elongatus PCC 7942, Anabaena sp. PCC 7120, Nostoc PCC 6310, Nostoc sp. PCC 9305), Drosophila melanogaster and nematodes [7]. In our experiments [16], the effects of two ketones (2-nonanone and 2-undecanone) on the cyanobacterial photosynthetic apparatus were very similar causing significant disturbances in the photosynthetic apparatus of cyanobacterium Synechococcus elongatus PCC 7942 by inhibition of electron transport through photosystem II. Ketones can participate in antagonistic interactions in the environment raising the question about the cellular targets, on which ketones act and about the mechanisms of their action. One of the possible experimental approaches to find an answer to this question is a genetic approach. Ketone-resistant mutants could be useful tools for gene identification and detection of ketone targets in cells.

The main goal of this study was to obtain 2-nonanone resistant mutants of the cyanobacterium Synechococcus elongatus PCC 7942 and to identify the corresponding mutated genes. In the present study, 2-nonanone resistant mutants have been obtained by transposon mutagenesis. Transposon insertions were localized in four different genes of Synechococcus elongatus PCC 7942.

\section{Materials and Methods}

\subsection{Bacterial Strains, Plasmids, and Growth Conditions}

Bacterial strains and plasmids used in the work are listed in Table 1.

The wild type of Synechococcus elongatus PCC 7942 (herein referred to as Synechococcus) (originated from the Moscow State University laboratory collection) and its derivative mutants were grown on solid $\left(1.2 \%\right.$ Bacto-agar) $\mathrm{BG} 11_{\mathrm{N}}$ medium that contains sodium nitrate or in liquid $\mathrm{BG} 11_{\mathrm{N}}$ medium [17] at $25^{\circ} \mathrm{C}$ and an illumination of $50 \mu \mathrm{mol}$ photons $\mathrm{m}^{-2} \mathrm{~s}^{-1}$. For growing of mutants, antibiotics were added into growth medium at the following concentrations: streptomycin (Sm; $2 \mu \mathrm{g} / \mathrm{mL}$ ), spectinomycin (Sp; 10 $\mu \mathrm{g} / \mathrm{mL})$, erythromycin (Em; $10 \mu \mathrm{g} / \mathrm{mL})$, kanamycin $(\mathrm{Km} ; 50 \mu \mathrm{g} / \mathrm{mL})$.

Escherichia coli strains were cultivated in the liquid Luria-Bertani (LB) medium or on Petri dishes with agarized LB medium (1.5\% agar) [18] at a temperature of $37^{\circ} \mathrm{C}$. Antibiotics were added at the following concentrations: streptomycin (Sm; $25 \mu \mathrm{g} / \mathrm{mL})$, spectinomycin (Sp; $50 \mu \mathrm{g} / \mathrm{mL})$, erythromycin (Em; $50 \mu \mathrm{g} / \mathrm{mL})$, kanamycin $(\mathrm{Km} ; 100 \mu \mathrm{g} / \mathrm{mL})$, ampicillin (Ap; $50 \mu \mathrm{g} / \mathrm{mL})$. 
Table 1. Characteristics of bacterial strains and plasmids used in the study.

\begin{tabular}{|c|c|c|}
\hline Strain & Characterization and/or Derivation & Reference or Origin \\
\hline \multicolumn{3}{|c|}{ Synechococcus elongatus } \\
\hline PCC 7942 & The wild type & Laboratory collection \\
\hline NR401(Tn) & $\mathrm{Sm}^{\mathrm{R}} \mathrm{Sp}^{\mathrm{R}} \mathrm{Em}^{\mathrm{R}}$; Tn5-692 mutant & This work \\
\hline NR385(Tn) & $\mathrm{Sm}^{\mathrm{R}} \mathrm{Sp}^{\mathrm{R}} \mathrm{Em}^{\mathrm{R} ; \mathrm{Tn} 5-692 \text { mutant }}$ & This work \\
\hline NR365(Tn) & $\mathrm{Sm}^{\mathrm{R}} \mathrm{Sp}^{\mathrm{R}} \mathrm{Em}^{\mathrm{R}} ; \mathrm{Tn} 5-692$ mutant & This work \\
\hline NR359(Tn) & $\mathrm{Sm}^{\mathrm{R}} \mathrm{Sp}^{\mathrm{R}} \mathrm{Em}^{\mathrm{R}} ; \mathrm{Tn} 5-692$ mutant & This work \\
\hline$\Delta \mathrm{NR} 401$ & $\mathrm{Km}^{\mathrm{R}}$; PCC 7942::p $\Delta \mathrm{NR} 401$, transconjugant & This work \\
\hline$\triangle \mathrm{NR} 385$ & $\mathrm{Km}^{\mathrm{R}}$; PCC 7942::p $\Delta \mathrm{NR} 385$, transconjugant & This work \\
\hline \multicolumn{3}{|c|}{ Escherichia coli } \\
\hline XL1-Blue & Host for routine cloning & $\begin{array}{c}\text { Collection of the Genetics } \\
\text { Department, Moscow } \\
\text { State University }\end{array}$ \\
\hline HB101 692 & HB101 harboring pRL692, $\mathrm{Sm}^{\mathrm{R}} \mathrm{Sp}{ }^{\mathrm{R}} \mathrm{Em}^{\mathrm{R}}$ & Laboratory collection \\
\hline HB101 443 & HB101 harboring pRL443, Ap ${ }^{R} \mathrm{Tc}^{\mathrm{R}}$ & Laboratory collection \\
\hline \multicolumn{3}{|c|}{ Plasmids } \\
\hline pRL692 & Carrying the mobile element ${ }_{R}$ Tn5-692, $\mathrm{Sm}^{\mathrm{R}} \mathrm{Sp}{ }^{\mathrm{R}} \mathrm{Em}$ & {$[19]$} \\
\hline pRL443 & Conjugal plasmid, derivative of $\mathrm{RP} 4, \mathrm{Ap}^{\mathrm{R}} \mathrm{Tc}{ }^{\mathrm{R}} ; \mathrm{Km}^{\mathrm{S}}$ & [20] \\
\hline pRL498 & $\mathrm{Km}{ }^{\mathrm{R}} ;$ plasmid vector for the direct selection & [21] \\
\hline pJet1.2/blunt & pMB1-ori bla eco47 IR::MCS; Ap ${ }^{\mathrm{R}}$ & Thermo Fisher Scientific \\
\hline pJet1.2-385 & Ap ${ }^{\mathrm{R}} ;$ pJet1.2:: $\Delta$ Synpcc7942_0726 & This work \\
\hline $\mathrm{p} \Delta \mathrm{NR} 401$ & $\mathrm{Km}^{\mathrm{R}} ;$ pRL498:: $\Delta$ Synpcc7942_1362 & This work \\
\hline $\mathrm{p} \Delta \mathrm{NR} 385$ & 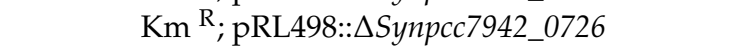 & This work \\
\hline
\end{tabular}

\subsection{Transposon Mutagenesis of Synechococcus}

Tn5-692 transposon (in plasmid pRL692; GenBank accession no. AF424805) was efficiently used earlier for mutagenesis of Synechococcus [19]. Transposon mutagenesis was carried out as we described in $[19,22]$ with some modifications. The transfer of the Tn5-692 transposon into the chromosome of Synechococcus was performed by triparental mating of cyanobacterium as a recipient with $E$. coli strains HB101, which harbor the Tn5-692 transposon on the plasmid pRL692 and conjugal plasmid pRL443 used for the mobilization of the plasmid pRL692 (Table 1). E. coli strains were grown in $3 \mathrm{~mL}$ LB with the appropriate antibiotic(s) and incubated at $37^{\circ} \mathrm{C}$ overnight. Cells of E. coli were diluted 1:20 and were grown for $1.5-2 \mathrm{~h}$ at $37^{\circ} \mathrm{C}$. Then E. coli cells were harvested from $1 \mathrm{~mL}$ of each bacterial culture by centrifugation and resuspended in $1 \mathrm{~mL}$ fresh LB. This step was repeated twice to wash the cells. After the third centrifugation, the cells were resuspended in $100 \mu \mathrm{L} \mathrm{BG11_{N }}$ medium. These cells were mixed with $100 \mu \mathrm{L}$ of concentrated 50-fold in BG11 $\mathrm{N}$ Synechococcus cells that were grown on a rotary shaker for 5 days before mating till $\mathrm{OD}_{\lambda}=700 \mathrm{~nm}$ 0.6-0.7. The conjugation mixture was incubated for $1 \mathrm{~h}$ in low light $\left(15 \mu \mathrm{mol}\right.$ photons $\left.\mathrm{m}^{-2} \mathrm{~s}^{-1}\right)$ at $25^{\circ} \mathrm{C}$. Then the cells were spread on sterile nitrocellulose filters (Millipore Corporation, Billerica, MA, USA) laid on BG11 ${ }_{N}+5 \%$ (vol/vol) LB agar plates (mating plates). The mating plates were incubated without antibiotic selection for $24 \mathrm{~h}$ in low light at $25^{\circ} \mathrm{C}$, and then the filters were transferred to BG11 $\mathrm{N}$ plates for $24 \mathrm{~h}$ incubation to give time for cyanobacteria to grow and only afterward the filters were transferred to BG11 ${ }_{N}$ plates with Sp $(10 \mu \mathrm{g} / \mathrm{mL})$ and Em $(10 \mu \mathrm{g} / \mathrm{mL})$. Transconjugant colonies were obtained on nitrocellulose filters after 15-20 days under light incubation. In the result of Tn5-692 mutagenesis, more than 2500 transposon mutants have been obtained on a selective medium containing antibiotics Sp, Em (transposon markers). 


\subsection{Selection of Synechococcus Mutants Resistant to 2-Nonanone Action}

Transposon mutants of Synechococcus were selected in the presence of high quantity (100 $\mu \mathrm{mol})$ of 2-nonanone (>99\% purity, Sigma-Aldrich Chimie GmbH, Steinheim, Germany). Ketone action was assayed as described in [7]. Colonies of mutants were replicated on the plates with agarized BG11 $\mathrm{N}$ medium. Wild type cells were used as control. Small aluminum foil boxes were placed on the surfaces of the agar in the center of the Petri dishes and filled with $100 \mu \mathrm{mol}$ of 2-nonanone; this quantity of ketone completely inhibits the growth of Synechococcus [7]. The plates were sealed with two layers of «Parafilm M» (Pechiney Plastic Packaging Company, Chicago, IL, USA). Colonies of mutants were incubated with 2-nonanone no less than a week. Mutants resistant to 2-nonanone (NR-mutants, "Nonanone Resistant") were selected for further investigations. After several rounds of verification of their growth ability at ketone presence, eleven 2-nonanone resistant mutants of Synechococcus have been selected. Four the most stable mutants-NR401(Tn), NR385(Tn), NR365(Tn), and NR359(Tn)-have been chosen for further investigations.

\subsection{Identification of Transposon Insertion Sites}

Genomic DNA was isolated from the wild type and the 2-nonanone resistant mutants of Synechococcus by using phenol-chloroform extraction as described in [23]. Genomic DNA from the mutants was completely digested during the night by the SalI enzyme according to the manufacturer's protocol (Fermentas, Thermo Fisher Scientific, Vilnius, Lithuania). The recognition site for SalI is absent inside of the transposon Tn5-692. DNA fragments were diluted and self-ligated (self-circularized) with T4 DNA ligase (Fermentas, Thermo Fisher Scientific, Vilnius, Lithuania) and used for the transformation of competent $E$. coli XL-Blue cells. Plasmid DNA was isolated from the $E$. coli transformants resistant to $\mathrm{Sm}(25 \mu \mathrm{g} / \mathrm{mL}), \mathrm{Sp}(50 \mu \mathrm{g} / \mathrm{mL}), \mathrm{Em}(50 \mu \mathrm{g} / \mathrm{mL})$ as these plasmids were supposed to carry the transposon Tn5-692 and flanking fragments of genomic DNA from the transposon insertion regions. For isolation of plasmid DNA, the GeneJET Plasmid Miniprep Kit (Fermentas, Vilnius, Lithuania) was applied. Isolated plasmids were sequenced with pW-TnR:923 L21 primer (Table 2) that was designed to the end of the transposon Tn5-692.

Table 2. DNA primers used for the amplification of nucleotide fragments.

\begin{tabular}{cc}
\hline Primer Name & Sequence \\
\hline pW-TnR:946 U21 & $5^{\prime}$-CTGCTGGCCATTGAGGACACC-3' \\
pW-TnR:923 L21 & $5^{\prime}$-CGGGAAACTCCTGAGCCAACT-3' \\
TN692 R-155 & $5^{\prime}$-GGCGTTGACATCACTCTG-3' \\
TN692 F-5485 & $5^{\prime}$-GTCTAGCTATCGCCATGTAAGC-3' \\
NR401-F & $5^{\prime}$-CCGAATTCGATGCTGTTAGAGG-3' \\
NR401-R & $5^{\prime}$-CCGAATTCGCTTCCAGCTCGAG-3' \\
NR385-F & $5^{\prime}$-CCGAATTCCTCTGGAAGACG-3' \\
NR385-R & $5^{\prime}$-CCGAATTCGCGTCTTGCATC-3' \\
NR365-F & $5^{\prime}$-CCGAATTCGAGAAGGCAGTG-3' \\
NR365-R & $5^{\prime}$-CCGAATTCGAGATCCGTGAC-3' \\
NR359-F & $5^{\prime}$-CCGAATTCGAAGACTTGCAAGC-3' \\
NR359-R & $5^{\prime}$-CCGAATTCGACGGTACTGGATG-3'
\end{tabular}

NR-primers were used to obtain amplicons that correspond to the deleted copies of the target genes. F- forward primer; $\mathrm{R}$-reverse primer.

The sequencing of DNA samples was performed using the ABI PRISM ${ }^{\circledR}$ BigDye $^{\mathrm{TM}}$ Terminator v.3.1 reagent kit (Applied Biosystems, ThermoFisher Scientific, Waltham, MA, USA). The reaction products were analyzed on an ABI PRISM 3100-Avant automatic sequencer at the Interinstitutional Center for Collective Use of the "GENOM" IMB RAS (http:www.genome-centre.narod.ru/). 


\subsection{Construction of Knockout-Mutants by Site-Directed Mutagenesis}

Site-directed mutagenesis was performed via homologous recombination of integrative plasmids bearing deleted copies of target genes with chromosomal DNA of the Synechococcus wild type. Partial copies of the Synpcc7942_1362 and Synpcc7942_0726 genes were amplified from Synechococcus DNA (Figure 1) with specific primers (Table 2). PCR was carried out on a Tercik DNA amplifier (DNA Technology, Moscow, Russia) by using DreamTaq PCR Master Mix (Fermentas, EU), under the following conditions: (1) with NR401-F/R primers: $95{ }^{\circ} \mathrm{C}$ for $2 \mathrm{~min}$, followed by 35 cycles at 95 ${ }^{\circ} \mathrm{C}$ for $30 \mathrm{~s}, 66{ }^{\circ} \mathrm{C}$ for $40 \mathrm{~s}, 72{ }^{\circ} \mathrm{C}$ for $1 \mathrm{~min}$, and the extension step $72{ }^{\circ} \mathrm{C}$ for $10 \mathrm{~min}$; (2) with NR385-F/R primers: $95{ }^{\circ} \mathrm{C}$ for $2 \mathrm{~min}$, followed by 35 cycles at $95{ }^{\circ} \mathrm{C}$ for $30 \mathrm{~s}, 66{ }^{\circ} \mathrm{C}$ for $40 \mathrm{~s}, 72{ }^{\circ} \mathrm{C}$ for $1 \mathrm{~min}$, and the extension step $72{ }^{\circ} \mathrm{C}$ for $10 \mathrm{~min}$. All DNA fragments were detected in the $1.5 \%$ agarose gel (VWR Life Science AMRESCO, Solon, OH, USA) stained by Ethidium bromide $(5 \mu \mathrm{g} / \mathrm{mL})$ (VWR Life Science AMRESCO, Solon, OH, USA) and irradiated with UV light with a wavelength of 302 nm (ECX-F15.M, Vilber Lourmat Electronic Ballast transilluminator, Merck KGaA, Darmstadt, Germany) and gel documentation system Gel Imager-2, GI-2, Helicon, Moscow, Russia). DNA fragments were purified using the Wizard SV Gel kit (Promega Corp, Madison, WI, USA) and from reaction PCR mixtures by the PCR Clean-Up System kit (Promega, Madison, WI, USA). GeneRuler 1 kb Plus DNA Ladder 75 to 20,000 bp (ThermoFisher Scientific, Waltham, MA, USA) was used for the sizing of DNA fragments during electrophoresis.

PCR product of the deleted fragment $(486 \mathrm{bp})$ of the Synpcc7942_1362 gene was directly cloned in the EcoRI site of the pRL498 vector (Figure 1A), producing a plasmid p $\Delta$ NR401 (Table 1). PCR product of the deleted fragment of the Synpcc7942_0726 (363 bp), firstly, was subcloned into the BglII site of pJet1.2/blunt vector (CloneJet PCR Cloning Kit, Fermentas) and afterward, it was cloned into the BamHI site of the pRL498 vector (Figure 1B), producing a plasmid p $\Delta$ NR385 (Table 1).

Plasmid transformation of the competent cells of E. coli XL-Blue, selection, and testing of transformants on the medium with $\mathrm{Km}(50 \mu \mathrm{g} / \mathrm{mL})$ were performed using standard techniques [24]. Obtained transformants were used for the further tri-parental mating with helper conjugative plasmid pRL443 for the conjugation transfer of $\mathrm{p} \Delta \mathrm{NR} 401$ and $\mathrm{p} \Delta \mathrm{NR} 385$ plasmids into Synechococcus wild type cells. Kanamycin-resistant transconjugants with plasmids integrated into the chromosome due to homologous recombination were selected on BG11 ${ }_{\mathrm{N}}$ agar plates supplemented with $100 \mu \mathrm{g} / \mathrm{mL}$ kanamycin, they resulting in $\Delta$ NR401 (PCC 7942::p $\Delta$ NR401) and $\Delta$ NR385 (PCC 7942::p $\Delta$ NR385) mutants, correspondingly. To evaluate the resistance of the obtained insertional mutants $\Delta N R 401$ and $\triangle$ NR385 to 2-nonanone, cells of these mutants were incubated on plates containing $100 \mu \mathrm{mol}$ 2-nonanone in the gaseous phase.

The diligent cloning of deleted copy of the gene Synpcc7942_0351 in E. coli cells was not successful due to unknown reasons. In the case of the very small gene Synpcc7942_0732, the inactivation has not been performed due to the lack of the sufficient size of this small fragment DNA for recombination. 
A

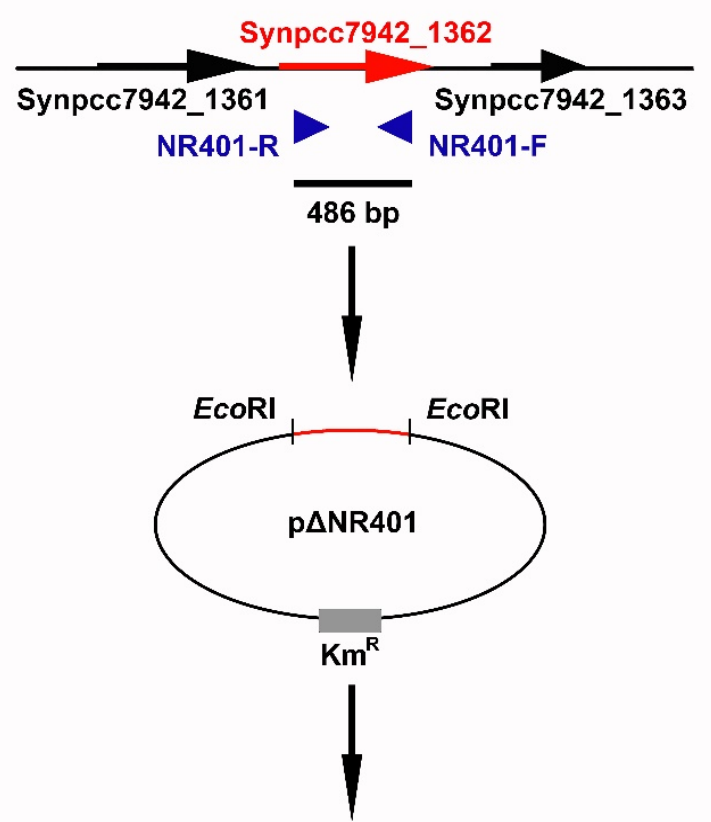

Conjugation

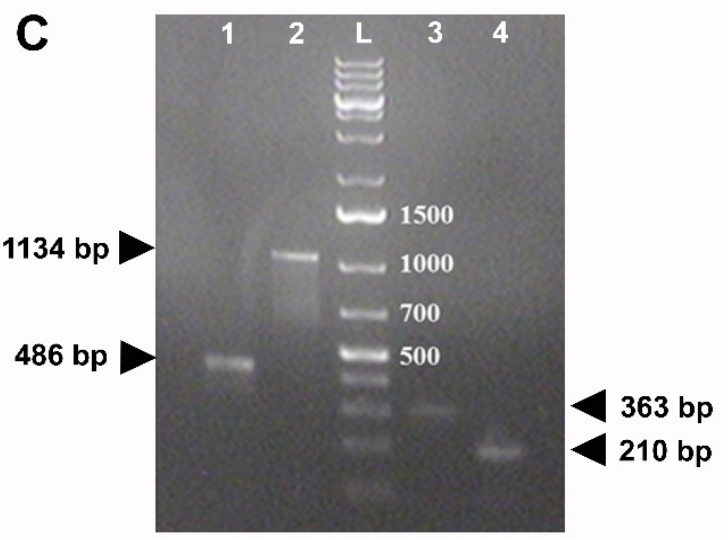

B
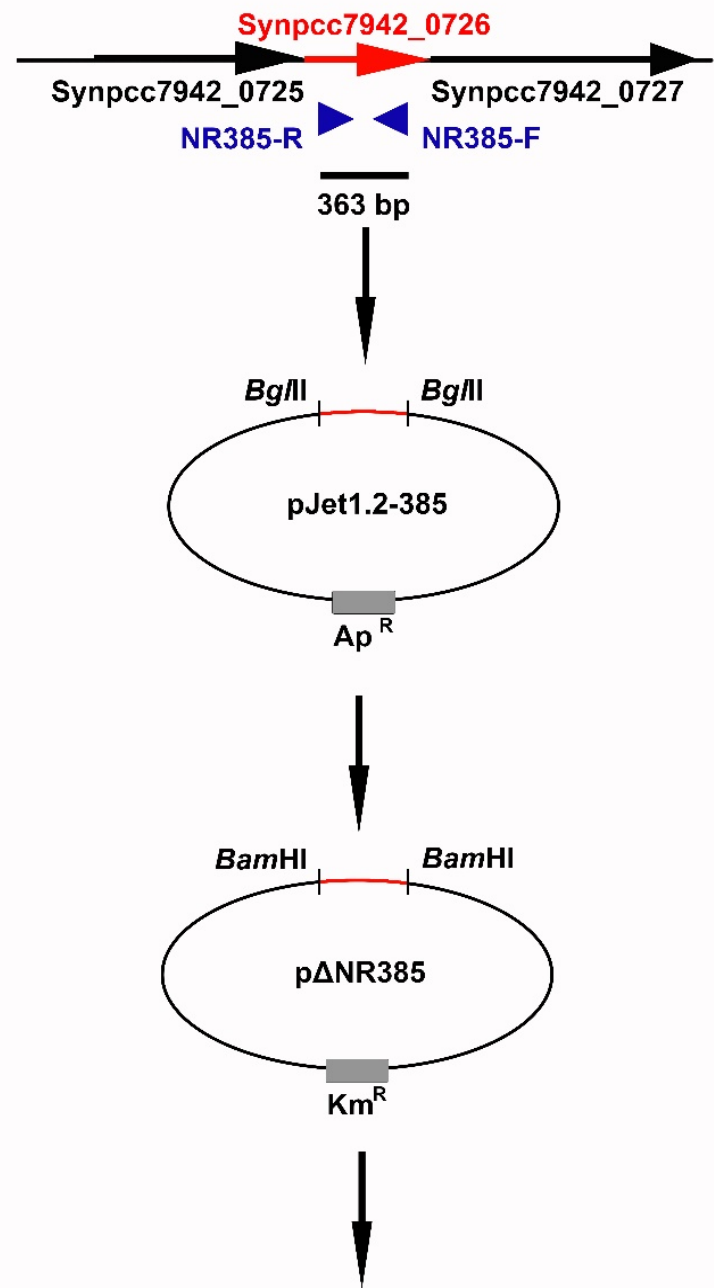

Conjugation

Figure 1. This scheme represents the genetic constructions that have been made by using the deleted copies of the target genes for site-directed mutagenesis of Synechococcus wild type cells. (A) Construction of a plasmid $\mathrm{p} \Delta \mathrm{NR} 401$. Deleted copy of the Synpcc7942_1362 gene was amplified and cloned into the pRL498 vector in EcoRI sites. Blue arrows correspond to primers. (B) Construction of a plasmid p $\triangle$ NR385. Deleted copy of Synpcc7942_0726 gene was amplified and cloned into pJet1.2/blunt vector. The fragment was digested in BglII/BamHI sites and cloned into pRL498 for further conjunction. Blue arrows correspond to primers. (C) Gel electrophoresis of the PCR products of the target genes. Lanes: 1 Synpcc7942_1362 (for $\Delta$ NR401), 2 Synpcc7942_0351 (for $\Delta$ NR365), 3 Synpcc7942_0726 (for $\Delta$ NR385), and 4 Synpcc7942_0732 (for $\Delta$ NR359), L-GeneRuler 1 kb Plus DNA ladder.

\subsection{Light Microscopy}

Morphological differences between the wild type of Synechococcus and the mutant cells were analyzed by using Zeiss Axiovert $200 \mathrm{M}$ inverted microscope equipped with Plan-Neofluar 100/1.3 oil immersion objective (Carl Zeiss GmbH, Jena, Germany) and supported by AxioVision SE64 Rel. 4.9.1 Software. Cell sizes were analyzed on the images recorded with a CCD-camera AxioCam MRc.5 (Carl Zeiss). The total number of cells counted was no less than 500 cells per sample. 


\subsection{Data Analysis}

Sequencing results were analyzed by using software BioEdit 7.2.5. The search for homologous nucleotide sequences was performed using the BLAST program (Basic Local Alignment Search Tool) in the GenBank database of the US National Center for Biotechnology Information (http://www.ncbi.nlm.nih.gov) and the full genome sequence of Synechococcus elongatus PCC 7942 (https://www.ncbi.nlm.nih.gov/nuccore/NC_007604.1). Identification of protein conserved domains was performed by NCBI Conserved Domain Database (CDD). Protein-protein interactions were analyzed by STRING (Protein-Protein Interaction Networks Functional Enrichment Analysis; https://string-db.org/ and by KEGG database (http://www.genome.jp/kegg/).

\section{Results}

\subsection{Localization of Tn5-692 Transposon Insertions in the Resistant Mutants of Synechococcus}

Tn5-692 transposon insertions were localized in four different genes (Synpcc7942_1362, Synpcc7942_0726, Synpcc7942_0351, Synpcc7942_0732) of the four corresponding mutants (NR401(Tn), NR385(Tn), NR365(Tn), and NR359(Tn) (Figure 2, Table 3).

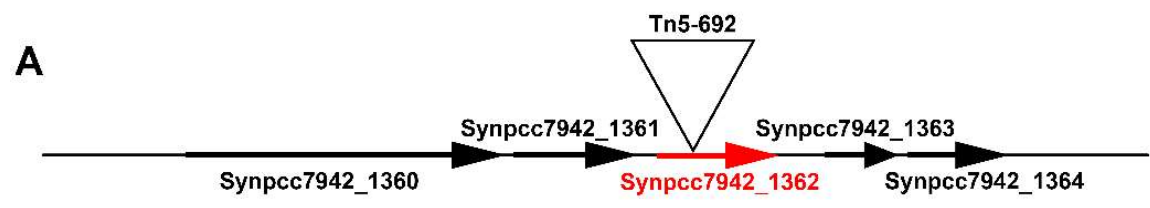

B

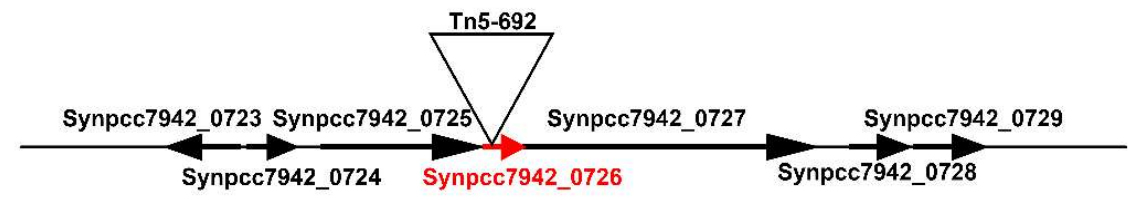

C

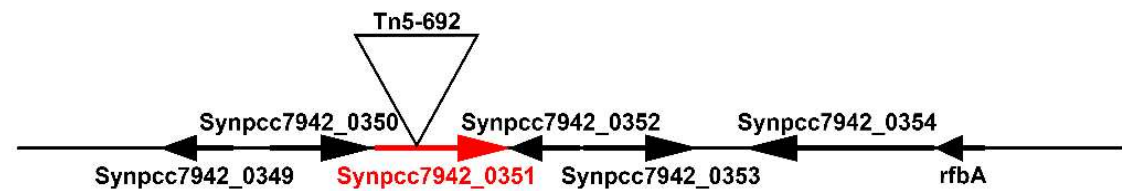

D

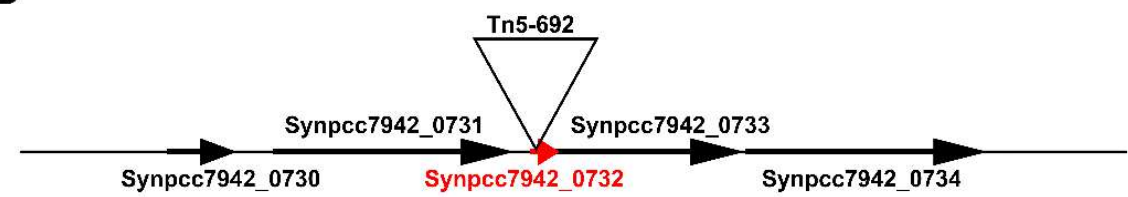

Figure 2. This scheme shows the transposon Tn5-692 localization in genomic regions of Synechococcus NR-mutants that were resistant to 2-nonanone. (A) Transposon insertion in Synpcc7942_1362 gene in NR401(Tn) mutant. (B) Transposon insertion in Synpcc7942_0726 gene in NR385(Tn) mutant. (C) Transposon insertion in Synpcc7942_0351 gene in NR365(Tn) mutant. (D) Transposon insertion in Synpcc7942_0732 gene in $\triangle \mathrm{NR} 359(\mathrm{Tn})$ mutant. 
Table 3. The genes and corresponding proteins, which were impaired in 2-nonanone-resistant mutants of Synechococcus.

\begin{tabular}{|c|c|c|c|c|}
\hline Mutant & Gene & Protein & Protein Function & Pathway \\
\hline$\Delta \mathrm{NR} 401(\mathrm{Tn})$ & Synpcc7942_1362 & $\begin{array}{l}\text { conserved hypothetical protein } \\
\text { (ABB57392.1) }\end{array}$ & $\begin{array}{c}\text { murein-peptide ligase (Mpl, UDP-N-acetylmuramate: } \\
\text { L-alanyl-gamma-D-glutamyl-meso-diaminopimelate ligase) }\end{array}$ & Biogenesis of cell wall \\
\hline$\Delta \mathrm{NR} 365(\mathrm{Tn})$ & Synpcc7942_0351 & $\begin{array}{l}\text { putative ABC transport system } \\
\text { substrate-binding proteins MlaD } \\
\text { (ABB56383.1) }\end{array}$ & $\begin{array}{l}\text { Protein is similar to } A B C \text { transporters providing the } \\
\text { resistance to organic solvents }\end{array}$ & $\begin{array}{l}\text { Phospholipid transport } \\
\text { pathway that maintains lipid } \\
\text { asymmetry in the outer } \\
\text { membrane }\end{array}$ \\
\hline$\Delta \mathrm{NR} 359(\mathrm{Tn})$ & Synpcc7942_0732 & $\begin{array}{l}\text { A small conserved hypothetical protein } \\
\text { ABB56764.1) of } 69 \text { amino acids with an } \\
\text { unknown function }\end{array}$ & $\begin{array}{c}\text { Gene belonging to phage gene cluster in the Synechococcus } \\
\text { genome and this protein is involved in interactions with } \\
\text { phage proteins }\end{array}$ & $\begin{array}{l}\text { Hypothetically cell membrane } \\
\text { modification }\end{array}$ \\
\hline$\Delta \mathrm{NR} 385(\mathrm{Tn})$ & Synpcc7942_0726 & $\begin{array}{l}\text { hypothetical protein (ABB56758.1) } \\
\text { containing the VRR-NUC domain }\end{array}$ & $\begin{array}{c}\text { Protein contains a Viral replication and repair (VRR) } \\
\text { nuclease (VRR nuc) domain. This functional unit is present } \\
\text { in the PD-(D/E)XK nuclease superfamily and repair } \\
\text { enzymes }\end{array}$ & DNA metabolism \\
\hline
\end{tabular}




\subsubsection{The Synpcc7942_1362 Gene Was Inactivated by Tn5-692 in the Mutant NR401(Tn)}

This gene encodes a conserved hypothetical protein (ABB57392.1) of Synechococcus with in silico predicted function of murein-peptide ligase (Mpl, UDP-N-acetylmuramate: L-alanyl-gamma-D-glutamyl-meso-diaminopimelate ligase), which is involved in the biogenesis of cyanobacteria cell wall (Table 3). According to STRING (https://string-db.org), hypothetical protein ABB57392.1 (Synpcc7942_1362) involves in protein-network (Figure 3) with three other proteins encoding by the its neighboring genes (Synpcc7942_1360, Synpcc7942_1361, Synpcc7942_1363) in Synechococcus genome. Two of them (ABB57390.1 and ABB57391.1) may be involved in cell envelope metabolism. Namely, the protein ABB57391.1 (Synpcc7942_1361) is a conserved hypothetical protein that contains a signal peptide and 8 pentapeptide repeats. The repeats were first identified in $\mathrm{HglK}$, which is required for the localization of heterocyst glycolipids. Other protein, ABB57390.1 (Synpcc7942_1360), is cell envelope-related transcriptional attenuator, polyisoprenyl-teichoic acid-peptidoglycan teichoic acid transferase [EC:2.7.8.-], which catalyzes the final step in cell wall teichoic acid biosynthesis. This enzyme participates in the transfer of the anionic cell wall polymers (APs) from their lipid-linked precursor to the cell wall peptidoglycan (PG) (https://www.uniprot.org/uniprot/Q02115).

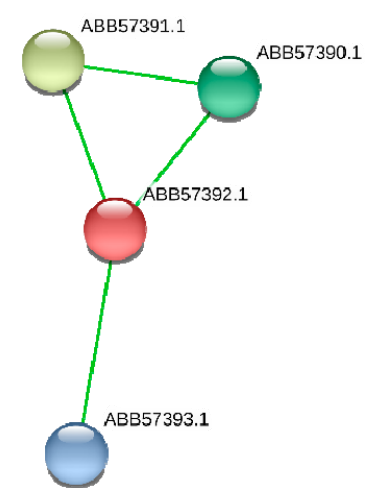

Figure 3. Network of ABB57392.1 protein (Synpcc7942_1362) and its protein partners according to STRING (https://string-db.org). In this figure: (1) protein ABB57391.1 (Synpcc7942_1361) is a conserved hypothetical protein that contains a signal peptide and 8 pentapeptide repeats; (2) ABB57390.1 (Synpcc7942_1360) is cell envelope-related transcriptional attenuator, polyisoprenyl-teichoic acid-peptidoglycan teichoic acid transferase [EC:2.7.8.-]; (3) protein ABB57393.1 (Synpcc7942_1363) is uncharacterized protein.

\subsubsection{In the Mutant NR365(Tn) the Transposon Was Inserted in the Synpcc7942_0351 Gene}

The product of the Synpcc7942_0351 gene belongs to the putative ABC transport system substrate-binding proteins MlaD (ABB56383.1), which is similar to ABC transporters providing the resistance to organic solvents (Table 3). It could be also pointed out that protein ABB56383.1 (Synpcc7942_0351) forms a network with protein partners (https://string-db.org) (Figure 4). Figure 4 shows such protein network, where two proteins belong to the MlaABCDEF system: the protein ABB56410.1 (Synpcc7942_0378) is MlaE, ABC transporter phospholipid/cholesterol/gamma-HCH transport system permease protein and the protein ABB56382.1 (Synpcc7942_0350) is MlaF, phospholipid/cholesterol/gamma-HCH transport system ATP-binding protein. Three other proteins are protein ABB57818.1 (Synpcc7942_1788), which is translocation and assembly module TamB protein; the protein ABB56590.1 (Synpcc7942_0558) is a conserved hypothetical protein, chaperone-like protein and the protein ABB57973.1 (Synpcc7942_1943) is cell division protein Ftn2-like, which contains CbpA region. It is known that Curved DNA-binding protein CbpA, contains a DnaJ-like domain, which is characteristic of DnaJ/Hsp40 (heat shock protein 40) proteins. They are highly conserved and play crucial roles in protein translation, folding, unfolding, translocation, and degradation. 


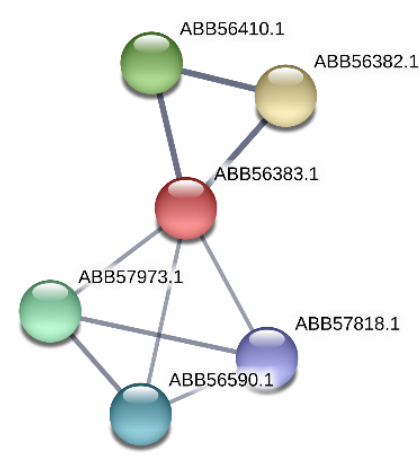

Figure 4. Network of ABB56383.1 protein (Synpcc7942_0351) and its protein partners according to STRING (https://string-db.org) is shown. In this figure: (1) protein ABB56410.1 (Synpcc7942_0378) is MlaE, ABC transporter phospholipid/cholesterol/gamma-HCH transport system permease protein; (2) protein ABB56382.1 (Synpcc7942_0350) is MlaF, phospholipid/cholesterol/gamma-HCH transport system ATP-binding protein; (3) protein ABB57818.1 (Synpcc7942_1788) is translocation and assembly module TamB protein; (4) protein ABB56590.1 (Synpcc7942_0558) is conserved hypothetical protein, chaperone-like protein; (5) protein ABB57973.1 (Synpcc7942_1943) is cell division protein Ftn2-like.

3.1.3. In the Mutant NR359(Tn) the Tn5-692 Transposon Was Inserted in the Synpcc7942_0732 Gene

In the mutant NR359(Tn) the Tn5-692 transposon sequence was flanked by the part of the Synpcc7942_0732 gene, which is described in the NCBI as encoding a small conserved hypothetical protein (ABB56764.1) of 69 amino acids with an unknown function. The gene belongs to the $23 \mathrm{~kb}$ phage gene cluster in Synechococccus elongatus PCC 7942 genome (Table 3). In bacterial systems, operon structure often reflects a shared biological function among the protein products of coexpressed genes. Several genes predicted to encode phage proteins, such as the putative phage terminase large subunit (Synpcc7942_0731), phage portal protein, lambda (Synpcc7942_0733), phage baseplate assembly protein V (Synpcc7942_0738), phage P2 protein GPJ (Synpcc7942_0740), phage tail protein I (Synpcc7942_0741), phage major tail tube protein (Synpcc7942_0748), phage tail tape measure protein TP901 (Synpcc7942_0750), core region and phage late control D protein GPD (Synpcc7942_0753), interspersed by several hypothetical conserved proteins. A lysozyme-encoding gene (Synpcc7942_0756) that is present downstream of this region may also be part of this gene cluster.

Moreover, protein ABB56764.1 (Synpcc7942_0732) forms network with protein partners (https://string-db.org) (Figure 5). They are encoding by genes that belong to this $23 \mathrm{~kb}$ island of phage genes.

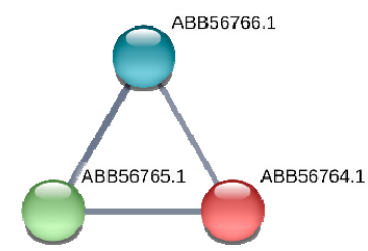

Figure 5. Network of ABB56764.1 protein (Synpcc7942_0732) and its protein partners according to STRING (https://string-db.org) is shown. In this figure: protein ABB56765.1 (Synpcc7942_0733) is the Phage portal protein, which belongs to the lambda family; protein ABB56766.1 (Synpcc7942_0734) is putative DNA primase/helicase.

\subsubsection{The Gene Synpcc7942_0726 Was Inactivated by Tn5-692 in the Mutant NR385(Tn)}

The gene Synpcc7942_0726 is predicted to encode a conserved hypothetical protein (ABB56758.1) containing the VRR-NUC (Virus-type Replication-Repair Nuclease) domain. This functional unit is present in the PD-(D/E)XK nuclease superfamily and repair enzymes; these enzymes contain a canonical nuclease catalytic domain typically found in type II restriction endonucleases (Table 3). 
According to STRING (https://string-db.org), the conserved hypothetical protein ABB56758 participates in protein-network with two other proteins that can be involved in DNA functionality (Figure 6). They are protein ABB56757.1 (Synpcc7942_0725) DEAD/DEAH box helicase-like enzyme and protein ABB56759.1 (Synpcc7942_0727) that is Mu-like_gpT domain-containing protein. Both protein-partners are encoding by genes that are in the same operon with the gene Synpcc7942_0726 that was impaired in the mutant NR385(Tn). In this operon (Synpcc7942_0724-Synpcc7942_0729) the other genes encode proteins, correspondingly: Synpcc7942_0724 encodes conserved hypothetical protein; Synpcc7942_0725 encodes DEAD/DEAH box helicase-like; Synpcc7942_0727 encodes a conserved hypothetical protein, containing the Zinc-binding domain of primase-helicase domain and topoisomerase-primase (TORPIM) nucleotidyl transferase/hydrolase domain; Synpcc7942_0728 and Synpcc7942_0729 are conserved hypothetical proteins.

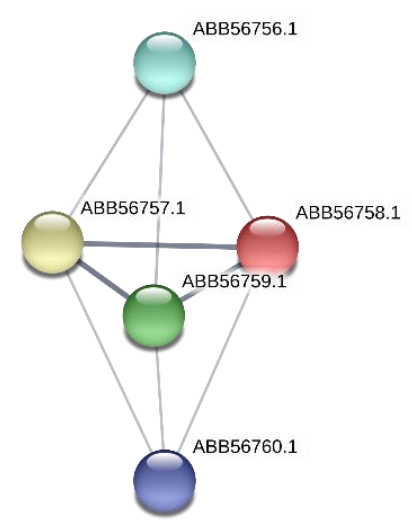

Figure 6. Network of ABB56758.1 protein (Synpcc7942_0726) and its protein partners according to STRING (https://string-db.org) is presented. In this figure: the protein ABB56756.1 (Synpcc7942_0724) and the protein ABB56760.1 (Synpcc7942_0728) are conserved hypothetical proteins; the protein ABB56757.1 (Synpcc7942_0725) is DEAD/DEAH box helicase-like enzyme; the protein ABB56759.1 (Synpcc7942_0727) is putative DNA primase/helicase.

\subsection{Directional Inactivation of Synpcc7942_1362 and Synpcc7942_0726 Genes}

Mutants $\triangle \mathrm{NR} 401$ and $\triangle \mathrm{NR} 385$ with directional inactivation of Synpcc7942_1362 and Synpcc7942_0726 genes have been obtained. These mutants demonstrated the same level of resistance to 2-nonanone action $(100 \mu \mathrm{mol})$ as the corresponding transposon mutants (Figure 7). Moreover, it was found that $\triangle \mathrm{NR} 401$ and $\triangle \mathrm{NR} 385$ mutants as well as corresponding transposon mutants were resistant to the $100 \mu \mathrm{mol}$ of 2-undecanone, revealing cross-resistance of these mutants to this class of VOCs. Mutants $\triangle$ NR401 and $\triangle$ NR385 demonstrated no difference in growth rate and pigmentation in comparison with the wild type strain.

Thus, the ketone-resistant phenotype due to localization of transposon in the Synpcc7942_1362 and Synpcc7942_0726 genes was successfully confirmed by the directed insertional inactivation of these genes. 


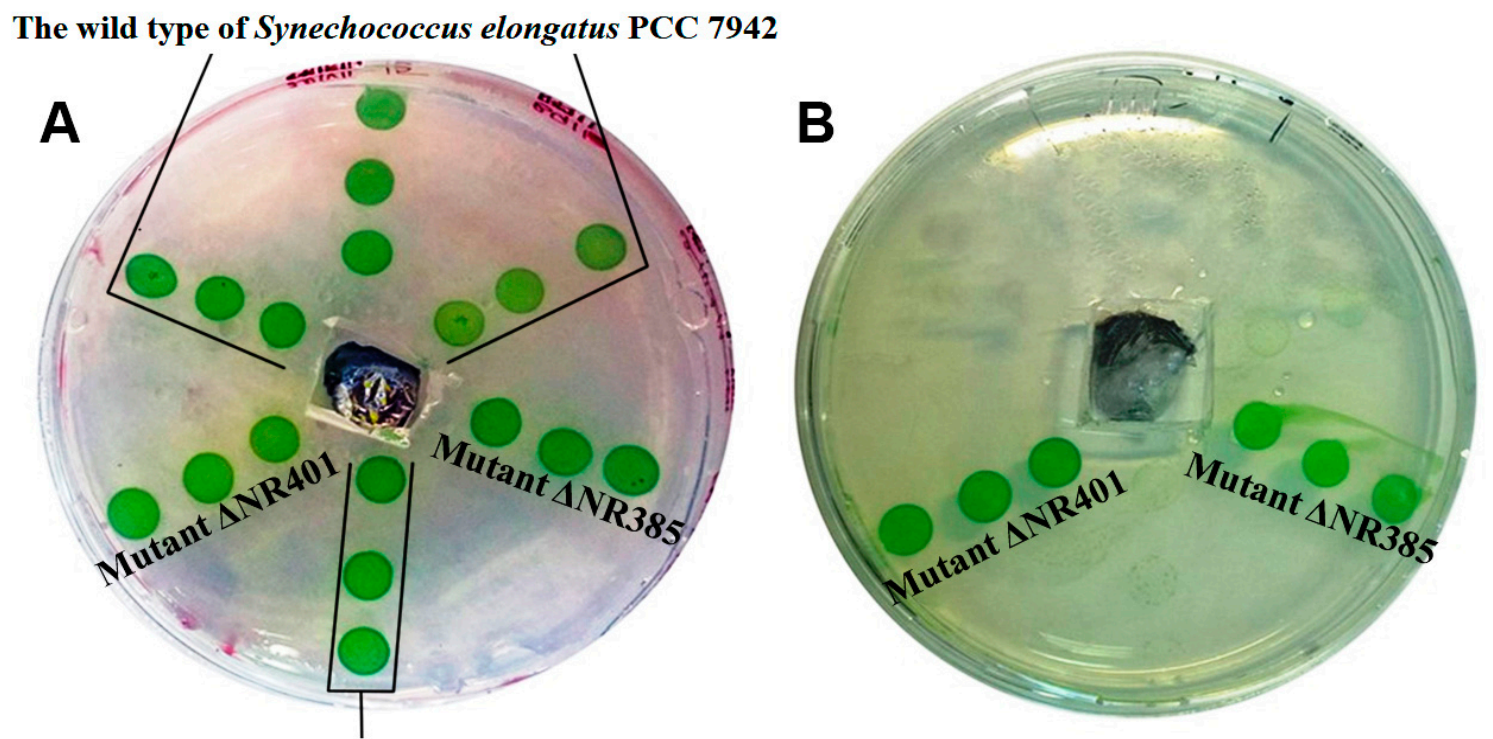

\section{The wild type of Synechococcus elongatus PCC 7942}

Figure 7. This figure shows the effect of 2-nonanone on the wild type of Synechococcus and the insertion of mutants $\triangle$ NR401 and $\triangle$ NR385. (A) Control plate. The growth of the wild type and mutant cells is similar. (B) $100 \mu \mathrm{mol}$ of 2-nononone was added. The growth of the wild type cells is inhibited. The mutants $\triangle \mathrm{NR} 401$ and $\triangle \mathrm{NR} 385$ demonstrated growth at the ketone presence.

\subsection{Morphological Characterization of $\triangle N R 401$ and $\triangle N R 385$ Mutants}

The average length of cells in the wild type of Synechococcus was $3.96 \pm 1.62 \mu \mathrm{m}$. The mutant $\triangle$ NR385 cells showed similar cell sizes $(3.95 \pm 1.44 \mu \mathrm{m})$ (Figure 8A). The significant increase in length was observed in the case of the $\triangle \mathrm{NR} 401$ mutant cells (Figure $8 \mathrm{C}$ ). At the same time, there were no significant morphological differences between the mutant $\triangle N R 385$ cells (Figure 8A) and the wild type cells (Figure $8 \mathrm{~B}$ ). The mutant $\triangle$ NR401 contained three size-types of cells that are visually diverse according to their length with the following sizes-15.7 $\pm 2.70 \mu \mathrm{m}, 26.93 \pm 3.84 \mu \mathrm{m}$, and $43.44 \pm 2.09 \mu \mathrm{m}$ (Figure $8 \mathrm{C}$ ). Thus, microscopic analysis revealed that the $\triangle$ NR401 mutant had a greater cell length (up to 4-10 times) in comparison with the wild type of Synechococcus.
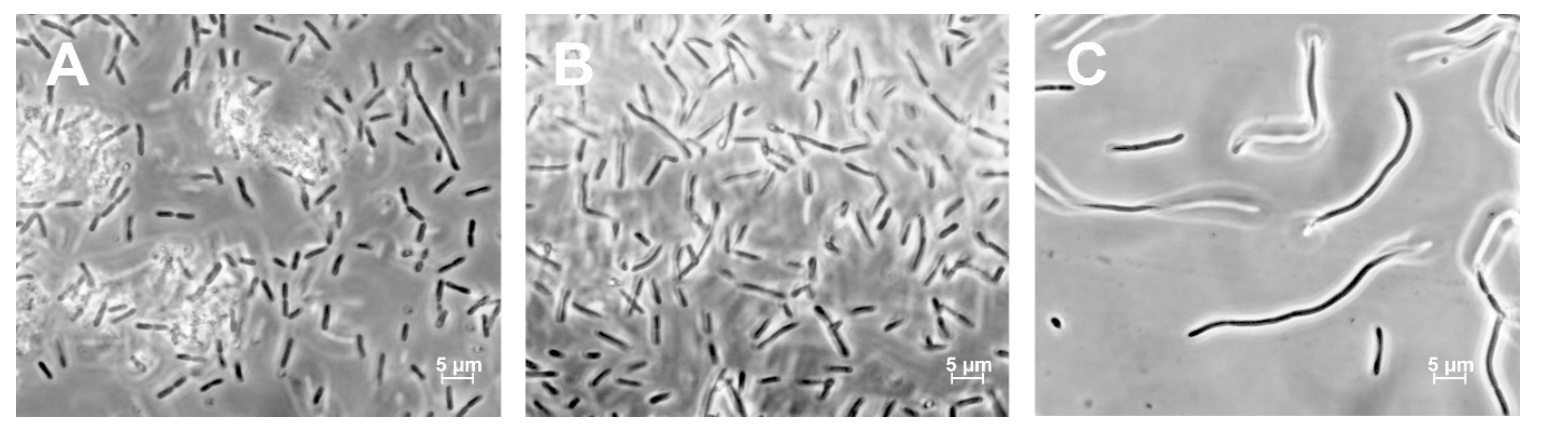

Figure 8. The wild-type and mutant phenotypes of Synechococcus. (A) Mutant $\Delta$ NR385. (B) The wild type of Synechococcus. (C) Mutant $\Delta$ NR401.

\section{Discussion}

4.1. Three Genes (Synpcc7942_1362, Synpcc7942_0351, Synpcc7942_0732) That Encode Proteins Involved in the Formation, Maintenance, and Functionality of Cyanobacterial Cell Wall

In the DNA of 2-nonanone resistant mutant NR401(Tn) the transposon Tn5-692 was found inserted in the gene Synpcc7942_1362 encoding conserved hypothetical protein Mpl (murein-peptide ligase, ABB57392.1; https://www.ncbi.nlm.nih.gov/protein/ABB57392.1). By using the site-specific 
mutagenesis, we have confirmed that disruption of the gene Synpcc7942_1362 contributes to the resistance of the mutant $\triangle \mathrm{NR} 401(\mathrm{Tn})$ to 2-nonanone.

The $m p l$ gene encoding L-alanyl- $\gamma$-D-glutamyl-meso-diaminopimelate ligase is well studied in Escherichia coli. The product of this gene is involved in the recycling L-alanyl- $\gamma$-D-glutamyl-meso-diaminopimelate, which are formed during the degradation of the peptidoglycan layer in bacteria cells during cell division [25]. Compounds formed due to the recycling process constitute $30-60 \%$ of the murein layer after the synthesis of a new cell wall in Gram-negative bacteria [26]. Recyclization of murein proceeds in parallel with the functioning of the enzymes MurC, MurD, and MurE, which participate in the biosynthesis of peptidoglycan de novo [27]. When the $m p l$ gene was inactivated in the E. coli strain, it turned out that the peptidoglycan content in the cells of this mutant did not decrease and that the absence of the product of this gene did not affect cell viability [25]. However, in the absence of murein peptide ligase activity, the content of the peptide triglycan precursor decreases by $50 \%$ in the mutant cells, and the products of peptidoglycan degradation presumably accumulate [25]. Therefore, it can be assumed that the presence of these products in the periplasmic space may represent an additional obstacle to the penetration of 2-nonanone molecules into the cytoplasm of cells and thus leads to the resistance of the mutant $\Delta$ NR401 cells to the action of this ketone.

It is known that bacterial cell division depends on normal peptidoglycan metabolism and synthesis [26-28]. Cell division is mediated by filaments of bacterial tubulin homolog FtsZ and protein FtsA (FtsAZ) that recruit septal peptidoglycan-synthesizing enzymes to the division site [29]. Defects in peptidoglycan synthesis in bacteria lead to elongated cell formation due to a violation of the division process [26]. In our study, we found that the mutant $\Delta$ NR401 characterized by long size cells (from $15.7 \pm 2.70 \mu \mathrm{m}$ to $43.44 \pm 2.09 \mu \mathrm{m}$ ) (Figure $8 \mathrm{C}$ ) in comparison with the wild type cells $(3.96 \pm 1.62 \mu \mathrm{m})$ of Synechococcus. The cell length of the wild type of Synechococcus is normally ranged between 2 and $10 \mu \mathrm{m}$ [30]. That is consistent with the data obtained in this study.

In the mutant NR365(Tn) cells transposon Tn5-692 inactivated a gene Synpcc7942_0351 that encodes the putative ABC transport system substrate-binding protein (ABB56383.1, https://www.ncbi.nlm.nih. gov/protein/ABB56383.1). This protein has a signal peptide and contains a conserved protein domain family MlaD. MlaD protein belongs to the ABC (ATP-binding cassette) transport system that actively prevents phospholipids accumulation at the cell surface in the absence of extracellular stress [31]. It was proposed that the MlaFEDB complex of $\mathrm{ABC}$ transporters is involved in a phospholipid transport pathway that maintains lipid asymmetry in the outer membrane by reverse transport of phospholipids from the outer membrane to the inner membrane in E. coli cells [31]. The MlaD protein functions in substrate binding and has a strong affinity for phospholipids and modulates ATP hydrolytic activity of the complex. This substrate-binding protein localizes on the periplasmic face of the inner membrane of E. coli cells with an uncleaved signal sequence [31]. Mla mutants of E. coli are relatively impermeable to most compounds except SDS-EDTA, and they exhibit no additional defects in lipopolysaccharides or outer membrane protein levels [31]. Phospholipid transport represents an important and so far unsolved problem of Gram-negative bacteria cell envelope biogenesis. New evidence was provided for anterograde phospholipid export by the Mla system [32]. The proposed model indicates that MlaA can both remove phospholipids from the outer membrane external leaflet and deliver them from MlaC into the outer membrane internal leaflet. Phospholipids monitored from the outer membrane external leaflet move in the retrograde direction, while phospholipids transported from the inner membrane move in the anterograde direction [32].

The Synpcc7942_0732 gene was found as a part of the $23 \mathrm{~kb}$ phage gene cluster in cyanobacteria chromosome. Cyanobacteria and phages coexist in nature and the gene transfer, loss, and exchange between these organisms are usual events in their co-evolution [33-36]. It is little known about resistance mechanisms of sea Synechococcus strains to phage [36]. We can hypothesize that some of the prophage proteins that are encoding by cyanobacteria genome probably may modify somehow the cell wall of cyanobacteria. In upcoming studies, it will be interesting to analyze the expression of the 
genes belonging to $23 \mathrm{~kb}$ island of phage genes in Synechococcus in different physiological conditions, including different stress conditions.

Thus, in three 2-nonanone resistant mutants of cyanobacterium Synechococcus transposon Tn5-692 damaged the genes, which encode proteins that could be involved in cell wall biogenesis and functionality. Cell membranes are the first barrier that defenses bacteria cells from different environmental factors and "takes the first blow". The VOCs are generally lipophilic compounds with high vapor pressure. They freely pass through biological membranes of producers and are released into the atmosphere or in the soil where the producers live. These molecules freely pass also through biological membranes of target organisms and may elicit changes in plasma membrane potential depolarization and activate regulatory proteins [37]. VOCs can interact with and damage lipid membranes [38] and interact with hydrophobic segments in proteins [13,39]. In our study, we found for the first time that ketone 2-nonanone can act on bacterial cells through different targets and by different mechanisms. It can affect peptidoglycan metabolism, $A B C$ transport Mla system activity, and phage-related proteins with unknown functions. Future experiments with the application of transcriptomic and proteomic methods may help to clarify more details of molecular mechanisms of ketone biological action.

\subsection{The Gene Synpcc7942_0726 Encodes Protein Involved in DNA Metabolism}

The gene Synpcc7942_0726, inactivated in the mutant NR385(Tn), encodes conserved hypothetical protein ABB56758.1 that possesses the VRR-NUC domain (viral replication and repair (VRR) nuclease (VRR nuc) domain). VRR-Nuc domains were first identified through a combination of sequence homology and secondary structure prediction [40]. It is associated with members of the PD-(D/E)XK nuclease superfamily, which include the type II restriction-modification enzymes [40]. The VRR-NUC domains are common and diverse in the genomes of bacteriophages and prophages and are involved in the replication and recombination of phage chromosomes [41]. Although the functions of the genes encoding the VRR-NUC domains are unknown, most of them are located in operons that include the DNA repair enzymes. Currently, the homologs of the endonuclease FAN1 (KIAA1018) are the only known eukaryotic proteins containing the VRR-NUC domain [42]. The first VRR-NUC domain structures using single-domain proteins derived from three bacteria and bacteriophage have been accomplished [42]. Probably, from these data authors concluded that, at least in bacteria and bacteriophage, VRR-NUC domains resemble Holliday-junction-resolving enzymes both structurally and functionally. The role of these domains in bacteriophage is so far unknown, but by analogy with systems such as $\lambda$ Rep, T7 endonuclease I, or T4 endonuclease VII it could be suggested that they may be involved in DNA replication, recombination, and packaging [43].

VOCs action on DNA repair [44,45] and gene transcription [46] has been reported for Escherichia coli. So, it was shown that E. coli strains that lack enzymes in the pathways of DNA repair, DNA metabolic process, and response to stress were highly sensitive to the VOCs of Muscodor albus [44]. VOCs permeabilize the bacterial cell membrane and induce disruption of cellular DNA metabolism through DNA damage. Possible mechanisms of VOCs resistance could include maintaining a robust DNA repair pathway, restricting uptake or increasing efflux of VOCs, detoxifying VOCs via modification of its chemical structure, or eliminating affected pathways that trigger cell death [45]. Until now we do not know the exact function of the VRR-NUC domain protein that is encoding by the gene Synpcc7942_0726 and that was inactivated in the 2-nonanone resistant mutant NR385(Tn) of Synechococcus. We hypothesize that mutation in this gene can probably decrease by some unknown mechanism an induction of the RecA-dependent DNA repair and apoptosis induction.

\section{Conclusions}

In the result of random transposon mutagenesis and a subsequent selection, the four 2-nonanone resistant mutants of Synechococcus were chosen for further identification of the impaired genes. Four different genes have been identified. These genes encode proteins with diverse functions and 
are involved in different cellular processes (Table 3, Figure 9). This observation permits to suggest that the 2-nonanone action on cyanobacteria cells may have several targets and can involve different mechanisms. In our study, we found three genes (Synpcc7942_1362, Synpcc7942_0351,Synpcc7942_0732) that encode proteins probably involved in the formation, maintenance and functionality of cell wall and one gene (Synpcc7942_0726) that encodes protein participated in DNA metabolism. Their possible functions and involvement in ketone-resistant mechanisms are discussed above.

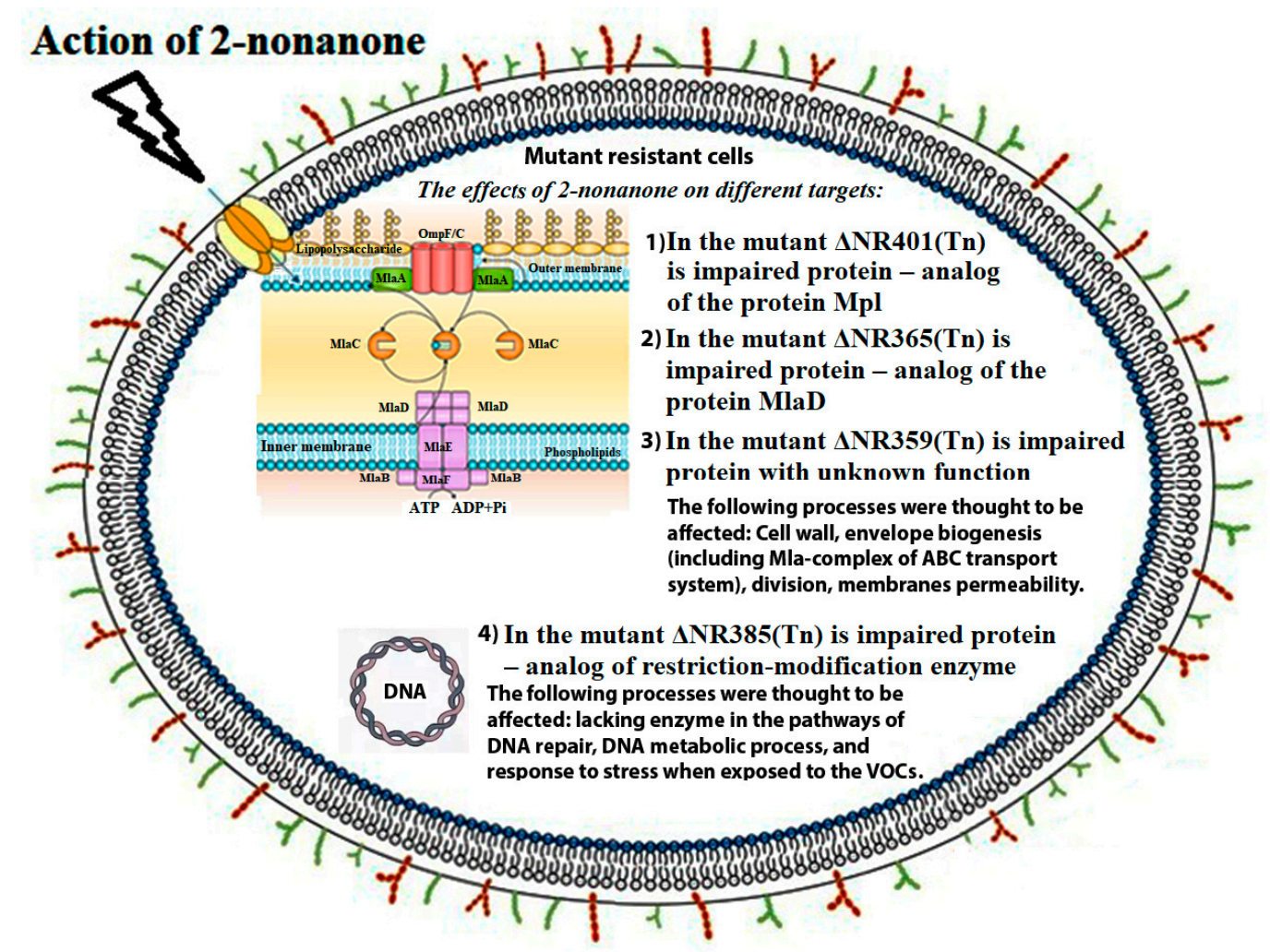

Figure 9. Modes of 2-nonanone action on cyanobacteria cell, (some figure elements are adapted from $[47,48])$.

This study provides new genetic data that shows the effect of 2-nonanone ketone on multiple targets in cells of the cyanobacterium Synechococcus. The biological effects of ketones are pleiotropic, and we are only taking the first steps towards understanding the molecular mechanisms of the complex picture of chemical interactions between organisms using VOCs as communication tools. Information about new genes, mutations in which lead to ketone resistance can also be useful for biotechnological applications in creating bacterial ketone producers. The obtained results allow us to set new tasks for the upcoming research of the molecular mechanisms of action of ketones on bacterial cells.

Author Contributions: For conceptualization, O.A.K.; formal analysis, O.A.K.; funding acquisition I.A.K. and O.A.K.; investigation, A.A.P. and O.A.K.; methodology, O.A.K.; project administration, O.A.K.; resources, O.A.K., I.A.K.; supervision, O.A.K.; validation, A.A.P. and O.A.K.; visualization, A.A.P., V.A.P., and O.A.K.; writing-O.A.K. and A.A.P.; writing-review and editing, O.A.K., V.A.P., I.A.K. All authors have read and agreed to the published version of the manuscript.

Funding: This research was funded by the Russian Foundation for Basic Research, grant number 18-04-00375.

Acknowledgments: The authors are grateful to the reviewers for very valuable comments, corrections, and suggestions during the final version of the manuscript preparation. The authors thank D.E. Sidorova for the useful comments during the manuscript editing. The work of A.A. Popova was partially supported by the Ministry of Science and Higher Education of the Russian Federation. The authors dedicated this paper to the memory of our beloved colleague V.A. Lipasova.

Conflicts of Interest: The authors declare no conflict of interest. 


\section{References}

1. Piechulla, B.; Degenhardt, J. The emerging importance of microbial volatile organic compounds. Plant Cell Environ. 2014, 37, 811-812. [CrossRef] [PubMed]

2. Lemfack, M.C.; Gohlke, B.O.; Toguem, S.M.T.; Preissner, S.; Piechulla, B.; Preissner, R. mVOC 2.0: A database of microbial volatiles. Nucl. Acids Res. 2018, 46, D1261-D1265. [CrossRef] [PubMed]

3. Veselova, M.A.; Plyuta, V.A.; Khmel, I.A. Volatile compounds of bacteria: Structure, biosynthesis, biological activity. Microbiology 2019, 88, 261-274. [CrossRef]

4. Koksharova, O.A. Cyanobacterial VOCs as allelopathic tools. In Bacterial Volatile Compounds as Mediators of Airborne Interactions; Ryu, C., Weisskopf, L., Piechulla, B., Eds.; Springer Nature Singapore Pte Ltd.: Singapore, 2020. [CrossRef]

5. Kai, M.; Haustein, M.; Molina, F.; Petri, A.; Scholz, B.; Piechulla, B. Bacterial volatiles and their action potential. Appl. Microbiol. Biotechnol. 2009, 81, 1001-1012. [CrossRef] [PubMed]

6. Effmert, U.; Kalderas, J.; Warnke, R.; Piechulla, B. Volatile mediated interactions between bacteria and fungi in the soil. J. Chem. Ecol. 2012, 38, 665-703. [CrossRef]

7. Popova, A.A.; Koksharova, O.A.; Lipasova, V.A.; Zaitseva, J.V.; Katkova-Zhukotskaya, O.A.; Eremina, S.I.; Mironov, A.S.; Chernin, L.S.; Khmel, I.A. Inhibitory and toxic Effects of Volatiles emitted by Strains of Pseudomonas and Serratia on Growth and Survival of selected Microorganisms, Caenorhabditis elegans and Drosophila melanogaster. BioMed. Res. Int. 2014, 2014, 125704. [CrossRef]

8. Schulz-Bohm, K.; Gerards, S.; Hundscheid, M.; Melenhorst, J.; de Boer, W.; Garbeva, P. Calling from distance: Attraction of soil bacteria by plant root volatiles. ISMEJ 2018, 12, 1252-1262. [CrossRef]

9. Giorgio, A.; De Stradis, A.; Lo Cantore, P.; Iacobellis, N.S. Biocide effects of volatile organic compounds produced by potential biocontrol rhizobacteria on Sclerotinia sclerotiorum. Front. Microbiol. 2015, 6, 1056. [CrossRef]

10. Means, G.E.; Feeney, R.E. Chemical Modification of Proteins; Holden-Day, Inc.: San Francisco, CA, USA, 1971; pp. 214-217.

11. Arulmurugan, S.; Kavitha, H.P.; Venkatraman, B.R. Biological activities of schiff base and its complexes: A review. RASAYAN J. Chem. 2010, 3, 385-410.

12. Damodaran, S.; Kinsella, J.E. Stabilization of Proteins by Solvents. Effect of $\mathrm{pH}$ and anions on the positive cooperativity of 2-nonanone binding to bovine serum albumin. JBC 1980, 255, 8503-8508.

13. Melkina, O.E.; Khmel, I.A.; Plyuta, V.A.; Koksharova, O.A.; Zavilgelsky, G.B. Ketones 2-heptanone, 2-nonanone, and 2-undecanone inhibit DnaK-dependent refolding of heat inactivated bacterial luciferases in Escherichia coli cells lacking small chaperon IbpB. Appl. Microbiol. Biotechnol. 2017, 101, 5765-5771. [CrossRef] [PubMed]

14. Plyuta, V.A.; Popova, A.A.; Koksharova, O.A.; Kuznetsov, A.E.; Khmel, I.A. The ability of natural ketones to interact with bacterial quorum sensing systems. Mol. Genet. Microbiol. Virol. 2014, 4, 167-171. [CrossRef]

15. Plyuta, V.; Lipasova, V.; Popova, A.; Koksharova, O.; Kuznetsov, A.; Szegedi, E.; Chernin, L.; Khmel, I. Influence of volatile organic compounds emitted by Pseudomonas and Serratia strains on Agrobacterium tumefaciens biofilms. APMIS 2016, 124, 586-594. [CrossRef] [PubMed]

16. Voronova, E.N.; Konyukhov, I.V.; Koksharova, O.A.; Popova, A.A.; Pogosyan, S.I.; Khmel, I.A.; Rubin, A.B. Inhibition of cyanobacterial photosynthetic activity by natural ketones. J. Phycol. 2019, 55, 840-857. [CrossRef] [PubMed]

17. Rippka, R.; Deruelles, J.; Waterbury, J.B.; Herdman, M.; Stanier, R.Y. Generic assignments, strain histories and properties of pure cultures of cyanobacteria. J. Gen. Microbiol. 1979, 111, 1-61. [CrossRef]

18. Miller, J.H. Experiments in Molecular Genetics; Cold Spring Harbor Laboratory Press: Cold Spring Harbor, NY, USA, 1974; pp. 14-66.

19. Koksharova, O.A.; Wolk, C.P. A novel gene that bears a DnaJ motif influences cyanobacterial cell division. J. Bacteriol. 2002, 184, 5524-5528. [CrossRef]

20. Elhai, J.; Vepritskiy, A.; Muro-Pastor, A.M.; Flores, E.; Wolk, C.P. Reduction of conjugal transfer efficiency by three restriction activities of Anabaena sp. strain PCC 7120. J. Bacteriol. 1997, 179, 1998-2005. [CrossRef]

21. Elhai, J.; Wolk, C.P. A versatile class of positive selection vectors based on the nonviability of palindrome-containing plasmids that allows cloning into long polylinkers. Gene 1988, 68, 119-138. [CrossRef] 
22. Karaushu, E.V.; Lazebnaya, I.V.; Kravzova, T.R.; Vorobey, N.A.; Lazebny, O.E.; Kiriziy, D.A.; Olkhovich, O.P.; Taran, N.Y.; Kots, S.Y.; Popova, A.A.; et al. Biochemical and Molecular Phylogenetic Study of Agriculturally Useful Association of a Nitrogen-Fixing Cyanobacterium and Nodule Sinorhizobium with Medicago sativa L. BioMed. Res. Int. 2015, 2015. [CrossRef]

23. Koksharova, O.; Schubert, M.; Shestakov, S.; Cerff, R. Genetic and biochemical evidence for distinct key functions of two highly divergent GAPDH genes in catabolic and anabolic carbon flow of the cyanobacterium Synechocystis sp. PCC 6803. Plant Mol. Biol. 1998, 36, 183-194. [CrossRef]

24. Sambrook, J.; Fritsch, E.F.; Maniatis, T. Molecular Cloning: A Laboratory Manual, 2nd ed.; Cold Spring Harbor Laboratory Press: Cold Spring Harbor, NY, USA, 1989; pp. 16-26.

25. Mengin-Lecreulx, D.; van Heijenoort, J.; Park, J.T. Identification of the rnpl gene encoding UDP-N-acetylmuramate: L-alanyl-yD-glutamyl-meso-diamilnopimelate ligase in Escherichia coli and its role in recycling of cell wall peptidoglycan. J. Bacteriol. 1996, 178, 5347-5352. [CrossRef] [PubMed]

26. Bramhill, D. Bacterial Cell Division. Annu. Rev. Cell Dev. Biol. 1997, 13, 395-424. [CrossRef] [PubMed]

27. Cohen, G.N. Peptidoglycan Synthesis and Cell Division. In Microbial Biochemistry, 2nd ed.; Springer: Dordrecht, The Netherlands, 2010; pp. 17-22. [CrossRef]

28. Koksharova, O.A.; Babykin, M.M. Cyanobacterial cell division: Genetics and comparative genomics of cyanobacterial cell division. Russ. J. Genet. 2011, 47, 255-261. [CrossRef]

29. Bisson-Filho, A.W.; Hsu, Y.P.; Squyres, G.R.; Kuru, E.; Wu, F.; Jukes, C.; Sun, Y.; Dekker, C.; Holden, S.; VanNieuwenhze, M.S.; et al. Treadmilling by FtsZ filaments drives peptidoglycan synthesis and bacterial cell division. Science 2017, 355, 739-743. [CrossRef] [PubMed]

30. Gorelova, O.A.; Baulina, O.I.; Rasmussen, U.; Koksharova, O.A. The pleiotropic effects of ftn2 and ftn6 mutations in cyanobacterium Synechococcus sp. PCC 7942: An ultrastructural study. Protoplasma 2013, 250, 931-942. [CrossRef]

31. Malinverni, J.C.; Silhavy, T.J. An ABC transport system that maintains lipid asymmetry in the gram-negative outer membrane. Proc. Natl. Acad. Sci. USA 2009, 106, 8009-8014. [CrossRef]

32. Hughes, G.W.; Hall, S.C.L.; Laxton, C.S.; Sridhar, P.; Mahadi, A.H.; Hatton, C.; Knowles, T.J. Evidence for phospholipid export from the bacterial inner membrane by the Mla ABC transport system. Nat. Microbiol. 2019, 4, 1692-1705. [CrossRef]

33. Avrani, S.; Wurtzel, O.; Sharon, I.; Sorek, R.; Lindell, D. Genomic island variability facilitates Prochlorococcus-virus coexistence. Nature 2011, 474, 604-608. [CrossRef]

34. Martiny, J.B.H.; Riemann, L.; Marston, M.F.; Middelboe, M. Antagonistic coevolution of marine planktonic viruses and their hosts. Annu. Rev. Mar. Sci. 2014, 6, 393-414. [CrossRef]

35. Silva, B.J.; Storms, Z.; Sauvageau, D. Host receptors for bacteriophage adsorption. FEMS Microbiol. Lett. 2016, 363. [CrossRef]

36. Zborowsky, S.; Lindell, D. Resistance in marine cyanobacteria differs against specialist and generalist cyanophages. Proc. Natl. Acad. Sci. USA 2019, 116, 16899-16908. [CrossRef] [PubMed]

37. Asai, N.; Nishioka, T.; Takabayashi, J.; Furuichi, T. Plant volatiles regulate the activities of $\mathrm{Ca}^{2+}$-permeable channels and promote cytoplasmic calcium transients in Arabidopsis leaf cells. Plant Signal. Behav. 2009, 4, 294-300. [CrossRef] [PubMed]

38. Trombetta, D.; Castelli, F.; Sarpietro, M.G.; Venuti, V.; Cristani, M.; Daniele, C.; Saija, A.; Mazzanti, G.; Bisignano, G. Mechanisms of Antibacterial Action of Three Monoterpenes. Antimicrob. Agents Chemother. 2005, 49, 2474-2478. [CrossRef] [PubMed]

39. Tromelin, A.; Andriot, I.; Guichard, E. Protein-flavour interactions. In Flavour in Food; Voilley, A., Etiévant, P.X., Eds.; Woodhead Publishing Limited: Cambridge, UK, 2006; pp. 172-207. [CrossRef]

40. Kinch, L.N.; Ginalski, K.; Rychlewski, L.; Grishin, N.V. Identification of novel restriction endonuclease-like fold families among hypothetical proteins. Nucleic Acids Res. 2005, 33, 3598-3605. [CrossRef] [PubMed]

41. Iyer, L.M.; Babu, M.M.; Aravind, L. The HIRAN domain and recruitment of chromatin remodeling and repair activities to damaged DNA. Cell Cycle 2006, 5, 775-782. [CrossRef]

42. MacKay, C.; Déclais, A.C.; Lundin, C.; Agostinho, A.; Deans, A.J.; MacArtney, T.J.; Hofmann, K.; Gartner, A.; West, S.C.; Helleday, T.; et al. Identification of KIAA1018/FAN1, a DNA repair nuclease recruited to DNA damage by monoubiquitinated FANCD2. Cell 2010, 142, 65-76. [CrossRef]

43. Sharples, G.J.; Curtis, F.A.; McGlynn, P.; Bolt, E.L. Holliday junction binding and resolution by the Rap structure-specific endonuclease of phage lambda. J. Mol. Biol. 2004, 340, 739-751. [CrossRef] 
44. Alpha, C.J.; Campos, M.; Jacobs-Wagner, C.; Strobel, S. Mycofumigation by the Volatile Organic Compound-Producing Fungus Muscodor albus Induces Bacterial Cell Death through DNA Damage. Appl. Environ. Microbiol. 2015, 81, 1147-1156. [CrossRef]

45. Hutchings, M.L.; Alpha-Cobb, C.J.; Hiller, D.A.; Berro, J.; Strobel, S.A. Mycofumigation Through Production of the Volatile DNA Methylating Agent N-methyl-N-nitrosoisobutyramide by Fungi in the Genus Muscodor. J. Biol. Chem. 2017, 292, 7358-7371. [CrossRef]

46. Yung, P.Y.; Grasso, L.L.; Mohidin, A.F.; Acerbi, E.; Hinks, J.; Seviour, T.; Marsili, E.; Lauro, F.M. Global transcriptomic responses of Escherichia coli K-12 to volatile organic compounds. Sci. Rep. 2016, 6, 19899. [CrossRef]

47. Bishop, R.E. Phospholipid middle management. Nat. Microbiol. 2019, 4, 1608-1609. [CrossRef] [PubMed]

48. Pei, G.; Chen, L.; Wang, J.; Qiao, J.; Zhang, W. Protein Network Signatures Associated with Exogenous Biofuels Treatments in Cyanobacterium Synechocystis sp. PCC 6803. Front. Bioeng. Biotechnol. 2014, 2, 48. [CrossRef] [PubMed]

(C) 2020 by the authors. Licensee MDPI, Basel, Switzerland. This article is an open access article distributed under the terms and conditions of the Creative Commons Attribution (CC BY) license (http://creativecommons.org/licenses/by/4.0/). 